\title{
KEY SUCCES FACTOR KEPEMIMPINAN PEREMPUAN DI PEMERINTAH DAERAH
}

\author{
Andy Arya Maulana Wijaya \\ Program Studi Ilmu Pemerintahan \\ Fakultas Ilmu Sosial dan Ilmu Politik, Universitas Muhammadiyah Buton \\ bulawambona.87@gmail.com
}

\begin{abstract}
Abstrak
Tujuan penelitian ini dilakukan untuk mengkaji sejumlah indikasi peran perempuan dalam kepemimpinannya di Pemerintah Daerah Kota Baubau. Penelitian di fokuskan pada dua tokoh pemimpin perempuan, yaitu Wakil Walikota Baubau Ibu Wa Ode Maasra Manarfa dan Sekretaris Daerah Kabupaten Buton Ibu Ichsana Maliki.

Penelitian ini menjelaskan latar belakang kehidupan pribadi dua tokoh pemimpin perempuan di daerah menjadi motivasi tersendiri bagi yang bersangkutan dalam berkiprah dalam politik lokal dan birokrasi daerah. Selain itu, motivasi pribadi juga menjadi factor penting bagi yang bersangkutan dalam bekarja termasuk sebagai pemimpin. Hasil penelitian ini menjelaskan bahwa, terdapat penciri khusus baggi pemimpin seorang perempuan yakni ketegasan, model pengambilan keputusan serta cara mengayomi bawahan, dan hal ini menjadikannya model kepemimpinan yang berbeda dengan laki-laki.
\end{abstract}

Kata Kunci: Kepemimpinan, Perempuan , Pemerintah Daerah 


\section{A. Latar Belakang}

Kiprah Perempuan dalam aktivitas public bukanlah satu fenomena baru. Perempuan dan kepemimpinan memiliki tempat yang menarik, setidaknya dalam Kabinet Kerja masa kepemimpinan Jokowi-JK terdapat 36 orang menteri dan 8 orang menteri diantaranya dipimpin oleh menteri perempuan. Ini adalah jumlah tertinggi keterlibatan perempuan dalam kabinet pemerintahan. Perempuan merupakan subyek pembangunan yang sangat penting. Dengan jumlah yang sangat besar perempuan dapat diperhitungkan sebagai aset pembangunan yang potensial. Namun sebagai sumber daya insani, perempuan hingga kini masih menghadapi berbagai permasalahan dan menghadapi berbagai ancaman khususnya dalam pembangunan peningkatan peran perempuan.

Peran Perempuan dalam sektor publik menarik untuk terus dikaji. Selain ini kajian mengenai gender akan tetapi topik ini erat kaitannya juga dengan perubahan sosial utamanya yang terjadi dalam peran dan kontribusi perempuan pada ranah publik. Terdapat dilema moral terhadap peran perempuan di sektor publik, dimana perempuan dalam tugas domestiknya di rumah tangga disaat yang sama diperhadapkan dalam tugasnya sebagai pejabat publik. Oleh karena tuntutan tugas demikian, tentu akan memberi implikasi pada salah satunya untuk kemudian terkorbankan demi sebuah prioritas pekerjaan.

$$
\text { Betapapun demikian, }
$$$$
\text { perkembangan peran kaum perempuan }
$$

dalam sector public memiliki keunikan tersendiri, utamanya dalam gaya kepemimpinan dan metode pengambilan keputusannya. Selain peran domestik sebagai ibu dan istri, seorang perempuan mempunyai tugas yang tidak kalah pentingnya yaitu peran publik, dimana kiprah dan sepak terjang kewanitaannya selalu ditunggu oleh masyarakat yang selalu butuh sosok perempuan.

Dalam beberapa contoh kasus peran perempuan dalam sektor publik justru memiliki sejumlah prestasi yang mampun menyangkal pertanyaan negative mengenai peran perempuan di sektor publik tersebut. Prestasi dan optimalnya pelaksanaan tugas menjadi indikator untuk menilai kinerja perempuan dalam sektor publik. Kondisi seperti diatas menjawab sebuah kondisi yang disebut pengarusutamaan gender, dimana gender dipahami sebagai perbedaan status sosial dan peranannya antara laki-laki dan perempuan.

Sejumlah kasus menarik tersebut bisa dilihat dari kinerja yang ditunjukkan oleh Menteri Perikanan Ibu Susi Pujiastuti, Walikota Surabaya Ibu Risma Harini, dan beberapa contoh pada kepala daerah di Indonesia. Hal ini mengindikasikan bahwa, streotipe tentang peran perempuan khususnya dalam sector public tengah mengalami pergeseran yang cukup signifikan. Peran perempuan lalu mulai diperhitungkan dalam menentukan sejumlah kebijakan, Pembangunan, Pelayanan Publik dan Pemberdayaan Masyarakat. 
Penggambaran seperti diatas ditengarai oleh perubahan sosial pada ranah public, khususnya pada peran perempuan di posisi penting dalam sektor publik. Disisi lain, penerimaan masyarakat untuk kemudian dipimpin oleh perempuan sudah bukan menjadi hal tabu lagi, sepanjang kinerja dan prestasi yang ditunjukkan sesuai dengan ekspektasi yang diinginkan dari sosok tersebut. Apalagi dalam kultur masyarakat buton yang menganggap bahwa keterlibatan perempuan dalam aktivitas public bukanlah hal yang tabu. Bahkan masyarakat buton mengakui bahwa perempuan sebagai pemimpin public bukanlah hal baru yang perlu dipertanyakan keefektifannya.

Dalam beberapa penelitian tentang gender dalam birokrasi public, menunjukkan adanya perbedaan yang signifikan dalam pengambilan keputusan oleh kepemimpinan yang dilakukan oleh perempuan. Disisi lain, aspek psikologis juga menuntut peran dan kontribusi perempuan dalam sektor publik.

Oleh karena itu, menarik untuk kemudian mengkaji peran-peran seperti itu dalam sektor publik di ranah lokal Kota Baubau. Dimana, hari ini sejumlah posisi penting dalam sektor publik misalnya pada sektor birokrasi maupun akademisi diisi oleh perempuan. Tentu ini memberi kondisi baru dalam menyimak dan mengkaji peran tersebut sebagai bagian kajian akademis, utamanya dalam menyoroti gaya kepemimpinan perempuan dalam organisasi dan pengambilan keputusan yang dilakukannya.
Penggambaran kondisi tersebut dalam penelitian ini dikaji sebagai gaya kepemimpinan perempuan di pemerintah daerah kota baubau. kajian akan difokuskan pada beberapa tokoh perempuan yang sekaligus sebagai pejabat atau pemimpin organisasi public dalam hal ini birokrasi didaerah. Tentu penelitian ini akan diurutkan pada urutan factual mengenai gaya kepemimpinan dan juga cara-cara pengambilan keputusan yang bersangkutan. Walau begitu, pada aspek lain penelitian ini berusaha menginformasikan topic-topik khusus yang berkaitan dengan perannya sebagai seorang perempuan dan aktivitasnnya pada birokrasi pemerintahan (konsep moral, kepedulian, tanggung jawab, jabatan serta keseimbangan antara keluarga dan jabatan public).

Penelitian ini dirasa akan memberikan sebuah informasi baru dalam memahami sisi kepemimpinan perempuan di Kota Baubau, disamping itu juga menjadi indicator dalam memahami perubahan sosial yang terjadi. Disisi lain, penelitian ini memfokuskan kajian perempuan dan ruang public di Kota Baubau, sehingga akan menambah khasanah diskusi akademis khususnya pada bidang kepemimpinan perempuan baik secara umum maupun khusus di Kota Baubau saja.

Dalam beberapa kasus, perempuan dan kepemimpinan merupakan hal yang belum begitu lazim bagi pemerintahan modern. Hanya saja, selalu saja ada regulasi yang 
memberikan wadah untuk itu. Maka penelitian ini akan meneliti sejumlah sukses faktor kepemimpinan perempuan dengan mengambil fokus pada Pemerintah Daerah. Selain itu, Penelitian kualitatif ini dilakukan dengan melakukan sejumlah wawancara dengan responden utama, yang kemudian di komparasikan dengan beberapa informasi baik dari berbagai literature relevan, maupun melalui informasi di media massa yang terkait dengan responden penelitian. Data yang terkumpul lalu dianalisis secara kualitatif, kemudian di lakukan reduksi seperlunya sepanjang masih relevan dengan maksud penelitian ini.

\section{Profil Dua Tokoh Perempuan}

Perempuan dalam posisinya pada ranah public, saat ini terus berkembang. Perempuan mulai berkiprah dalam beberapa posisi strategis di daerah, termasuk sebagai pemimpin pada organisasi maupun instansi di daerah. Penelitian ini memfokuskan kajian pada dua tokoh perempuan, yakni Ibu Maasra Manarfa yang menjabat sebagai Wakil Walikota Baubau dan Ibu Ichsana Maliki yang menjabat sebagai Sekretaris Daerah Kabupaten Buton (beliau pensiun pada bulan April 2016, hanya saja dalam proses penelitian yang bersangkutan masih menjabat).

Dra. Hj. Wa Ode Maasra Manarfa, M.Si adalah seorang Wakil Walikota Baubau periode 2013-2018. Terlahir dari orang tua dan keluarga yang akrab dengan kekuasaan dan politik. Terbukti menjabat sebagai anggota DPRD (sejak akan dikemukakan pula sejumlah factor yang mempengaruhi keterlibatan perempuan pada sektor publik saat ini.

\section{B. Metode Penelitian}

masih bersama dalam Kabupaten Buton hingga menjadi daerah otonom Kota Baubau). Ayah menjadi sosok inspiratifnya, dimana Bapak La Ode Manarfa yang pernah menjabat sebagai salah satu Anggota DPR RI masa presiden Soeharto. Jabatan dalam sector public menurut Ibu Maasra adalah amanah, yang memiliki arti berbeda dengan perannya dalam wilayah privat. Baginya, perempuan itu harus kuat jika dipercaya, sebagai ibu tetap dijalankan dengan baik, juga tugas dalam birokrasi dan pengambilan keputusan juga dijalankan dengan baik, itulah konsep kuatnya perempuan baginya.

Dra. Wa Ode Ichsana Maliki, adalah birokrat murni. Memulai karirnya sebagai pegawai negeri mulai dari pangkat dan golongan paling bawah. Berkat karya dan dedikasinya beliau di percaya sebagai Sekretaris Daerah Kabupaten Buton (hingga April 2016). Berasal dari keluarga yang sering berpindah-pindah daerah, karena ayahnya adalah seorang hakim. Untuk itu, menurut beliau pendidikan begitu penting memotivasinya untuk maju dan memperbaiki kehidupan keluarga. Ada sejumlah filosofi yang dipegang beliau dalam keterlibatannya pada sector public, misalnya jangan mengambil hak milik orang lain dan kalau pelayanan kepada masyarakat dilakukan dengan baik, maka keluarga akan ditolong pula. Motivasi paling besar dalam bekerja 
dengan baik dan professional adalah keinginan untuk memberikan contoh kepada kaum perempuan lainnya.

\section{Konsep Gender dan Gaya Kepemimpinan}

Penelitian ini beranjak pada pemahaman mengenai peran perempuan dalam studi kajian gender. Dimana, Gender digunakan untuk membedakan pria dan wanita secara sosial. Gender ada untuk menilai dan membedakan manusia bukan dari segi fisik, melainkan peran dan fungsinya dalam masyarakat sosial. Selain itu, gender juga bersifat relatif dan kontekstual. Gender bersifat relatif ditinjau dari segi budaya dan masyarakat mana yang memandang gender tersebut.

Pada konsep ini, responden merupakan masyarakat buton yang turut serta mempengaruhi cara pandang masyarakat terhadap kepemimpinan perempuan. Sejarah memang menggambarkan kerterlibatan perempuan, dimana raja pertama dan kedua dalam kerajaan Buton kuno di pimpin oleh perempuan. Begitu juga dalam cara pandang masyarakat buton tidak terlalu mendikotomikan antara peran perempuan dalam ranah public. Hanya saja, perempuan dalam sector publik utamanya sebagai pemimpin jarang ditemui. Alasan yang mendasari hal ini perlu di lakukan observasi lanjutan, hanya saja untuk tulisan ini tidak begitu relevan.

Gender Menurut Doyle (1985; dalam Situmorang, 2011) adalah konsep yang digunakan untuk menggambarkan perbedaan antara laki-laki dan perempuan secara sosial budaya. Perbedaan ini mengacu kepada unsure emosional dan kejiwaan, sebagai karakteristik sosial dimana hubungan laki-laki dan perempuan dikonstruksikan sehingga berbeda tempat dan waktu. Misalnya perempuan dikenal sebagai makhluk lemah lembut, cantik, emosional dan keibuan sedangkan laki-laki dianggap kuat, rasional, jantan dan perkasa. Perbedaan ini menimbulkan ketidakadilan yang dialami kaum perempuan yang bersumber pada penandaan (stereotype) yang dilekatkan kepada mereka banyak sekali. Diantaranya anggapan bahwa perempuan memiliki pembawaan "emosional" sehingga perempuan tidak tepat tampil sebagai pemimpin atau manajer (Fakih, 2009).

Perempuan sebagai pemimpin lebih mengutamakan konsep diri sebagai ibu, sehingga lebih menekankan pada kasih sayang. Responden mengakui bahwa dalam mengawasi pekerjaan bawahannya seringkali dilakukan dengan intensif, hanya saja jika terdapat beberapa kesalahan pendekatan yang dilakukan untuk mengkoreksinya adalah melalui nasehat. Namun, seringkali ketegasan yang ditunjukkan begitu berbeda dengan apa yang ditunjukkan oleh pemimpin laki-laki, dimana hal ini di akui oleh bahwan responden yang merasa nasehat dalam bentuk tindakan lebih menggerakkan perasaan bawahan untuk berubah ketimbang perkataan keras dari pemimpin laki-laki. 
$\begin{array}{ccr}\text { Dalam } & \text { artikelnya tentang } \\ \text { kepemimpinan } & \text { perempuan } & \text { Faraz }\end{array}$ (2013) dengan mengutip apa yang menjadi tesis Tannen bahwa pemimpin yang menekankan pada hubungan dan keakraban yang cenderung dimiliki oleh perempuan, memungkinkan seorang pemimpin tersebut bersikap memberdayakan segenap anggotanya, serta menekankan struktur organis. Sedangkan pemimpin yang menekankan pada status dan kemandirian, yang cenderung dimiliki oleh laki-laki memungkinkan pemimpin tersebut mengadopsi struktur hirarkis, spesialisasi, dan perintah. Argument ini menjadi kerangka yang bisa dibuktikan pada kondisi karakteristik budaya masyarakat yang berbeda.

Selain itu juga, Penelitian tentang hubungan gender dan kepemimpinan juga dikemukakan oleh Sara Levinson, seorang Presiden Properti NFL, Inc di New York. Ia mengungkapkan pertanyaan secara langsung dalam sebuah tanya jawab dengan seluruh anggota laki-laki yang ada di timnya. Ia bertanya kepada mereka: "Apakah kepemimpinan saya berbeda dengan laki-laki?" Jawab mereka: "ya" (dikutip dalam Sudarmo, 2008). Jawaban ini cukup memberikan dukungan bahwa ada perbedaan gaya kepemimpinan antara perempuan dan laki-laki.

a. Perempuan cenderung lebih memiliki perilaku yang demokratis dan partisipatif, seperti hormat pada orang lain, perhatian pada orang lain, Gaya seperti ini mengacu pada kepemimpinan interaktif, gaya seperti ini memiliki unsur-unsur kepemimpinan yang transformasional, yakni yang inspirasional.

b. Berbeda dengan laki-laki yang ang cenderung lebih mengarah pada perilaku yang directive (mendasarkan pada instruksi) dan assertive (cenderung agresif dan dogmatik), dan menggunakan otoritas yang biasanya ia miliki untuk melakukan "kontrol dan komando (Faraz, 2013).

Sedangkan kerangka penelitian ini memandang sebuah kepemimpinan sebagai sebuah cara-cara efektif seseorang dalam merealisasikan program-programnya dalam sebuah organisasi dan kemampuan menggerakkan bawahannya. Konsep ini erat dengan gaya kepemimpinan seseorang. Gaya kepemimpinan disebut juga sebagai style yang berarti corak atau mode seseorang yang tidak banyak berubah dalam mengerjakan sesuatu, hal ini karena gaya merupakan kesanggupan, kekuatan, cara, irama, ragam, bentuk, lagu, metode yang khas dari seseorang untuk bergerak serta berbuat sesuatu, dengan demikian yang bersangkutan mendapat penghargaan untuk keberhasilannya dan kejatuhan nama bila mengalami kegagalan (Syafi'ie, 2009).

Mencermati penjelasan tersebut, penelitian ini menganggap bahwa kepemimpinan antara perempuan dan laki-laki memiliki rangkaian karakteristik unik tersendiri. Sehingga menarik untuk kemudian diangkat 
kedalam ranah akademis, betapapun demikian bahwa penelitian serupa pernah dilakukan namun karakter budaya dan kondisi masyarakat juga memiliki pengaruh dalam gaya kepemimpinan seseorang (Sudarmo, 2009).

\section{E. Kepemimpinan dan Perempuan di Pemerintahan Daerah}

Fenomena kepemimpinan perempuan dalam berbagai sector public bukan saja menjadi wacana penyetaraan saja, namun prakteknya sudah begitu massif dapat diamati. Sebut saja misalnya Menteri, Anggota DPR/DPRD, Bupati/ Walikota, Kepala SKPD, Kepala Desa dan lain-lain. Ini menunjukkan adanya perubahan paradigm terkait peran dan posisi perempuan disektor public. Disisi lain, apa yang dilakukan ataupun dijabat oleh perempuan seringkali lekat dengan efek psikologis yang dimiliki oleh perempuan.

Penelitian yang menghubungkan gender dengan gaya kepemimpinan umumnya mengarah ke gaya kepemimpinan tertentu yang terlihat khas perempuan. Dalam Analisa Situmorang (2011) dengan melihat sejumlah indicator tertentu menrumuskan bahwa secara umum ada 2 (dua) gaya kepemimpinan khas perempuan yakni (1) Kepemimpinan maskulin-feminim dan Kepmimpinan transformasionaltransaksional.

Bass, Avolio, dan Atwater (1996; dalam Situmorang, 2011) menemukan bahwa laki-laki umumnya lebih menampilkan kepemimpinan transaksional dibandingkan perempuan. Sebaliknya, perempuan lebih memperlihatkan kepemimpinan transformasional dibanding kan lakilaki. Carless menemukan bahwa manajer perempuan lebih menggunakan kepemimpinan transformasional dibandingkan manajer laki-laki.

Menurut Natalie Porter dan Jessica Henderson Daniel, (2007: 249) Banyak kualitas yang diperlukan untuk memiliki kepemimpinan organisasi yang efektif pada situasi sekarang ini yakni berkualitas dan umumnya diasosiasikan dengan Kemimpinan Transformasional (Bass,1985; Burn,1978; Chia-Chen, 2004; dalam Situmorang, 2011), dan juga diasosiasikan dengan para Pemimpin Wanita (Applebaun, Audet, Miller, 2002; dalam Situmorang, 2011).

Betapapun indikasi psikologis menjadi domain terbesar dalam mempengaruhi gaya kepemimpinan perempuan, namun karateristik pekerjaan maupun tingkat jabatan juga akan mempengaruhi gaya kepemimpinan perempuan. Dalam hasil penelitian Nina Zulida Situmorang (2011) mengemukakan bahwa karakteristik atau tuntutan pekerjaan dapat mempengaruhi gaya kepemimpinan perempuan. 


\section{F. Kesimpulan}

Terlepas dari anggapan bahwa peran perempuan cenderung terabaikan dalam kepemimpinan sector public, namun hari ini peran-peran perempuan dalam sector public menjadi begitu penting. Salah satunya sebagai pemimpin dalam pemerintahan daerah, perempuan memberikan gaya kepemimpinan yang lebih terbuka, ketegasan, cara pengambilan keputusan serta cara mengayomi bawahan yang menjadi pembeda dengaan gaya kepemimpinan oleh laki-laki.

\section{DAFTAR PUSTAKA}

Anastasi, A dan Urbina, S. 1997. Psychological Testing, Simon \& Schuster Co., New Jersey.

Doyle, James A. 1985. Sex and Gender : The Human Experience Wn.C. Brown Publisher, Iowa.

Faisal, Sanapiah. 2005. Format-Format Penelitian Sosial. Jakarta: PT.Grafindo Persada.

Fakih, M. 1996. Analisis Gender dan Transformasi Sosial, Pustaka Pelajar, Yogyakarta.
Fakih, Mansour, 2008. Cet.v. Runtuhnya Teori Pembangunan dan Globalisasi, Yogyakarta: Pustaka Pelajar dan Insist Press.

Miles dan Huberman, 2009. Analisis Penelitian Kualitatif, Jakarta: UI Press.

Naqiyah, Najlah. 2005. Otonomi Perempuan, Jawa Timur: Bayumedia.

Nurhaeni, Ismi Dwi Astuti, 2009. Gender dan Strategi Pengarusutamaanya di Indonesia. Yogyakarta: Pustaka Pelajar.

Situmorang,Nina Zulida, 2011. Gaya Kepemimpinan Perempuan, Procedding PESAT (Psikologi, Ekonomi, Sastra, Arsitektur \& Sipil) Vol. 4 Oktober 2011 ISSN: 1858-2559, Jakarta: Universitas Gunadarma

Syafi'ie, Inu Kencana, 2009. Kepemimpinan Pemerintahan Indonesia, Bandung: Refika Aditama 